\title{
東日本大震災後の犯罪に関する研究 (2)
}

\author{
一震災被害の大きさや復旧の遅れなどが狖盗の発生数に与えた影響— \\ ○森 丈弓 ${ }^{1} \cdot$ 岡本英生 ${ }^{2} \cdot$ 阿部恒之 ${ }^{3} \cdot$ 齊藤豊治 $^{4}($ 非会員 $) \cdot$ 山本雅昭 ${ }^{5}$ (非会員) \\ 松原英世 ${ }^{6}$ (非会員) $・$ 平山真理 ${ }^{7}$ (非会員) ・ 小松美紀 ${ }^{8}$ (非会員 $) \cdot$ 丹羽菜摘 ${ }^{9}$ (非会員) \\ $\left({ }^{1}\right.$ 甲南女子大学人間科学部・ ${ }^{2}$ 奈良女子大学生活環境科学系・ ${ }^{3}$ 東北大学大学院文学研究科 $\cdot{ }^{4}$ 大阪弁護士会 \\ ${ }^{5}$ 静岡大学人文社会科学部・ ${ }^{6}$ 愛媛大学法文学部・ ${ }^{7}$ 白鴎大学法学部・ ${ }^{8}$ 吹田市立教育センター・ ${ }^{9}$ 厚真町農業委員会) \\ キーワード : 犯罪, 自然災害, 東日本大震災
}

\begin{abstract}
A study on the crime after the Great East Japan Earthquake
Takemi MORI ${ }^{1}$, Hideo OKAMOTO ${ }^{2}$, Tsuneyuki $\mathrm{ABE}^{3}$, Toyoji SAITO $^{4, \#}$, Masaaki YAMAMOTO ${ }^{5, \#,}$ Hideyo MATSUBARA ${ }^{6, \#}$, Mari HIRAYAMA ${ }^{7, \#}$, Miki KOMATSU ${ }^{8, \#}$, and Natsumi NIWA ${ }^{9, \#}$
\end{abstract}

( ${ }^{1}$ Faculty of Human Sciences, Konan Women's Univ., ${ }^{2}$ Division of Human Life and Environmental Sciences, Nara Women's Univ., ${ }^{3}$ Graduate School of Arts and Letters, Tohoku Univ., ${ }^{4}$ Osaka Bar Association, ${ }^{5}$ Faculty of Humanities and Social Sciences, Shizuoka Univ.,

${ }^{6}$ Faculty of Law and Letters, Ehime Univ., ${ }^{7}$ Faculty of Law, Hakuoh Univ., ${ }^{8}$ Suita Education Center, ${ }^{9}$ Atsuma Town)

Key Words: crime, natural disaster, the Great East Japan Earthquake

\section{目 的}

大規模災害のあとには犯罪発生が抑制されやすいと言われ るが，実際には火事場泥棒的な便乗犯罪が発生するなど，必 ずしも治安状況が良好なわけでない。2011年 3 月に発生した 東日本大震災のあとも, 公式な統計では被災地における犯罪 発生の総数は減っているものの, 多数の便乗犯罪が報道され ている。災害被害の方が大きく犯罪被害を届ける余裕がない 被災者もいると考えられることから, 大規模苂害後の犯罪発 生の実情について知るためには, 公式統計に頼らない方法 (住 民による犯罪被害の報告）が必要になる。また, そもそも災 害と犯罪の関係についてはまだ分かっていないことが多く, 災害によるどのような影響が犯罪発生を誘発しやすいのかと いうことについて, 研究成果が十分に積み重なっているわけ ではない。

阪神淡路大震災後の被荻地で行われた調査では，震災被害 の大きさや復旧の遅さが窃盗事犯の発生に影響を与えていた

(齊藤，2013)。震苂直後の混乱の大きさや，その状態の持続 期間の長さが, 犯罪発生, 特に窃盗を誘発しやすいと思われ る。また, ルーティン・アクティビティ理論に従えば，たと えば避難のために家を空けると, 監視者がいなくなり, 犯罪 者が無人の家に忍び込んで突盗を行いやすくなる。さらに, もともと高齢者が多いなどの地域的な特性も犯罪者の侵入を 容易にする要因かもしれない。

そこで, 本研究では, 東日本大震災後の被災地の住民を対 象に調查を行い, 震災被害の程度, 避難の有無, そして地域 の特性などが窃盗犯罪の発生にどのように影響しているかを 明らかにする。

$$
\text { 方 法 }
$$

方法Web 調查。

対 象 者 宮城県及び福島県に在住の計 1030 人(いずれも調 查を委託した調査会社のモニタ一会員。男性 643 人, 女性 387 人。 $18 \sim 81$ 歳)。

調査内容「窃盗犯罪」: 東日本大震災発生から 1 年間の間に, 自転車・オートバイ盗, 自動車盗, ガソリン盗, そして住宅 への空き巣の被害にあったかどうかを尋ねた。いずれか 10 でも被害にあったことがある場合を有とし，それ以外を無と した。「避難」: 東日本大震災後に避難をしたかどうか（一時 的に避難して元の居住場所に戻った場合と避難したまま元の 居住場所に戻らなかった場合の両方を含む）を回答してもら った。「停電期間」: 東日本大震災による停電がいつまで続い たかを尋ねた。停電が解消されるまでの日数をデータとして 用いた。「震災被害(建物)」: 住んでいる地域で震災により全
壊または半壊した家やビルがあったから゙うか尋ねた。「震災被 害(人)」:住んでいる地域で震災により亡くなった人がいたか どうか尋ねた。「地域特性」: 住んでいる地域の特性について, 「一人暮らしが多い」「高齢者が多い」な゙にあてはまるかど うかを答えてもらった。その他:「年齢」と「性別」を答えて もらった。

調查時期： 2012 年 12 月。

\section{結 果}

「窃盗犯罪」を従属変数とし，その他の要因を独立変数と するロジスティック回帰分析を行った。変数増加法により有 意な独立変数のみ残るようにしたところ, 最終的には, 「避難」 (オッズ比 2.273), 「停電期間」(オッズ比 1.028), そして「震 災被害(人)」(オッズ比 2.623)のみが残った(Hosmer-Lemeshow の検定 $\left.\chi^{2}=7.091, \mathrm{df}=7, \mathrm{p}=.419\right)$ 。結果は表 1 に示した。

\section{表1「窃盗犯罪」を従属変数とする ロジスティック回帰分析結果}

\begin{tabular}{ccc}
\hline & オッズ比 & 有意確率 \\
\hline 避難 & 2.273 & .02 \\
停電期間 & 1.028 & .02 \\
震災被害(人) & 2.623 & .01 \\
\hline
\end{tabular}

\section{考 察}

震災後に避難している者ほど, 停電期間が長かった者ほど, そして地域で亡くなった人がいるという者ほど铅盗被害にあ っていたということになる。停電期間の長さと死亡者がいる ということと犯罪発生との関連については，阪神淡路大震災 後の調査でも明らかになっていたことであるが，今回の調査 からはさらに避難という要因も大きく影響していることが分 かった。

\section{引用文献}

齊藤豊治編 (2013). 大災害と犯罪 法律文化社

本研究は, 公益財団法人日工組社会安全財団 2012 年度研究 助成により行われた。 